\title{
Consumer's Attitude towards Ramadan Advertising
}

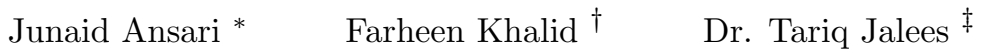 \\ Muhammad Sufyan Ramish §
}

\begin{abstract}
Advertising in the Ramadan is at peak in Pakistan and other Muslim countries. It now resembles other festival theme based advertising. In view of the lack of the studies on the issue, this study has adopted the constructs commonly used in measuring attitude towards advertising. The adopted questionnaire was administered to a population of 320, and the valid sample size was 303. After ascertaining normality, validity and reliability, initially overall model was tested through multiple regressions. Subsequently hypotheses were tested separately through simple regression. The study found that entertainment, information, credibility and good for economy and irritation positively influences consumers' attitude towards advertising. The study has validated all the results, except irritation. This relationship is positive in this study but is inconsistent to earlier studies that found negative relationship between irritation and attitude. Media industry will benefit from the finding of this study in developing right communication strategy on Ramadan Theme advertising. This study has not explored the effects of demographic factors and moderating effect of different media, which could be incorporated in future research.
\end{abstract}

Keywords: Ramadan advertising, attitude towards ramadan advertising, information, credi-bility, entertainment and irritation.

\section{Introduction}

Ramadan is the only religious festival in which family members in early morning (Sehry) and evening (Mugrib/Iftar) watch TV together for a whole month. In view of this large TV audience, these timings have become highly lucrative for advertisers. Most of the companies, target the slots due to which both advertising cluttering and advertising rates also increase significantly (Mazhar, 1998; El-Bakry, 2001). This study has operationalized attitude towards advertising as Ramadan theme advertising.

Most of the populaces in Pakistan and other Muslim countries generally do a lot of shopping in this month, due to which companies also spend significantly in their advertising communications (Fattah, 2005). Both local and international brands in their Ramadan's advertisements also add spiritual content in their jingles and videos to make them more relevant to Ramadan (Odabasi \& Argan, 2009). Media houses also sponsor

\footnotetext{
*Institute of Business Management, Karachi, Pakistan

$\dagger$ Institute of Business Management, Karachi, Pakistan

¥ Karachi Institute of Economics and Technology, Karachi, Pakistan

$\S$ Institute of Business Management, Karachi, Pakistan
} 
TV and game shows and other informative programs in this month. Some of them are relevant to Ramadan while others are not. Nevertheless, a large audience watches these programs/advertisements and they have high rating. Companies target those programs slots for their advertisement that have high rating. A controversial issue with Ramadan advertising is that it promotes extravagant spending whereas Islam prohibits wasteful and excessive spending (Gharib, 1992; Osman, 1998; Gatehouse, 2001).

In the context of attitude towards advertising mostly studied factors are entertainment, information, irritation and credibility. Perhaps this is the first study that has attempted to use good for economy in addition to the above four factors for measuring their effects on attitude towards Ramadan advertising (Evans \& Hoy, 2016; Jung, Shim, Jin, \& Khang, 2016; Sandikci \& Omeraki, 2007).

Most of the earlier studies are of generalized nature and these studies have not used any stimuli while obtaining the responses of the subject (Rengarajan \& Sathya, 2014). The problem in this approach is that subjects might respond on the perception of different brands. To address the issue respondents were shown a Pepsi's advertisement? Pepsi, lighting up the lives prior to the administration of the questionnaire. Print version of the electronic advertisement shown to the respondent (L. Cohen, Manion, \& Morrison, 2013).

Earlier studies have not adequately integrated their results into theory. The constructs used in this study are mostly related to non-Ramadan advertising; mainly because they have not been used in it, earlier. One of the contributions of this study is that it has successfully extended these constructs in a conceptual framework of Ramadan themes based advertisement (Bhave, Jain, \& Roy, 2013; Rajabi, Dens, De Pelsmacker, \& Goos, 2017).

This gap in the literature has motivated the authors to undertake a study for measuring the influence entertainment, information, irritation, credibility and good for economy on attitude towards Ramadan Theme based Advertising.

\section{Literature Review}

Consumer attitude towards advertising have been used extensively in different context but not in the context of Ramadan advertising. A few qualitative studies have used information and entertainment in the context of Ramadan Advertising (Sandikci \& Omeraki, 2007). In view of the lack of studies on Ramadan advertising, this study has measured the effects of "entertainment, irritation, Information and credibility" on attitude towards advertising. Some studies found that attitude towards advertising vary on demographic factors, Dahlen, Rosengren, and Smit (2014); Park (2015) but these factors were not considered in this study as they were beyond its scope.

Advertising mediums such as print and electronic have different effects on consumer's attitude, (Usmani \& Dawani, 2013) have mostly measured attitudes and have not considered the mediating and moderating roles of these mediums (L. Cohen et al., 2013). Consumers' attitude towards an advertisement does not always reflects their real attitude as brand image of the advertisement also influences their attitude and behavior (Tina \& Buckner, 2006). 
Informative advertising when matches with consumers need will positively influence their purchase intentions and actual behavior. Attitude towards advertising and purchase intention also depends on factors including credibility and irritation (Daniel \& Raman, 2014; Kim \& Han, 2014). Literature also, supports that factors value, perceived levels of entertainment, information, and irritation affects consumer attitudes towards advertising. Studies also support that economy and materialism positively influences consumers' attitude towards advertising (J. Cohen, 2014; Opree, Buijzen, van Reijmersdal, \& Valkenburg, 2014).

Source credibility mostly refers to credibility of endorsers, spokesperson, medium or the individual shown in the ad. Consumers have positive attitude towards those advertisements, which have more than one celebrities and have emotional appeal. Some strongly believe that newspaper is a more credible medium than television. Therefore, information in the newspapers will have more reliability and believability in comparison to Television (Tucciarone, 2015).

\section{Theoretical Background}

Theory of reasoned action was developed in by Fishbein and Ajzen (1975), which was further extended in 1975. Since then, this theory has widely been used to study the attitude and human behavior. There are several studies that derived hypotheses on the basis of TRA and developed their conceptual models for predicting the attitude and behavior. Such studies include the studies on advertising strategies and consumers' attitude towards advertising (Bauer, Reichardt, Barnes, \& Neumann, 2005; Ducoffe, 1996). This study also focuses on customers' attitude towards advertising and the hypotheses developed in this study were derived from the relationships defined by theory of reasoned action.

\section{Conceptual Framework}

The conceptual framework extended through theoretical model (i.e. TRA) is depicted in Figure 1, followed by discussions that support the derived relationships of the conceptual framework.

\section{Attitude towards Ramadan Advertising}

Consumer's attitude towards an advertisement is a key factor that predicts its acceptance or rejection (Ling, Piew, \& Chai, 2010). Attitude towards an ad is referred as "a learned predisposition to respond in a consistently favorable or unfavorable manner toward advertising in general" (MacKenzie \& Lutz, 1989). Most of the studies on this issue have measured the effect of attitude on advertising without any stimuli (Mittal, 1994; Noor, Sreenivasan, \& Ismail, 2013). Religiosity besides having a direct effect on consumer attitude towards advertising also have moderating effect on the relationship between attitude towards product and purchase intention (Naseri \& Tamam, 2012). Attitude although have been measured as a uni-dimensional construct, but studies suggest it is more appropriate 
to measure it through multi-items (Helm, Moulard, \& Richins, 2015).

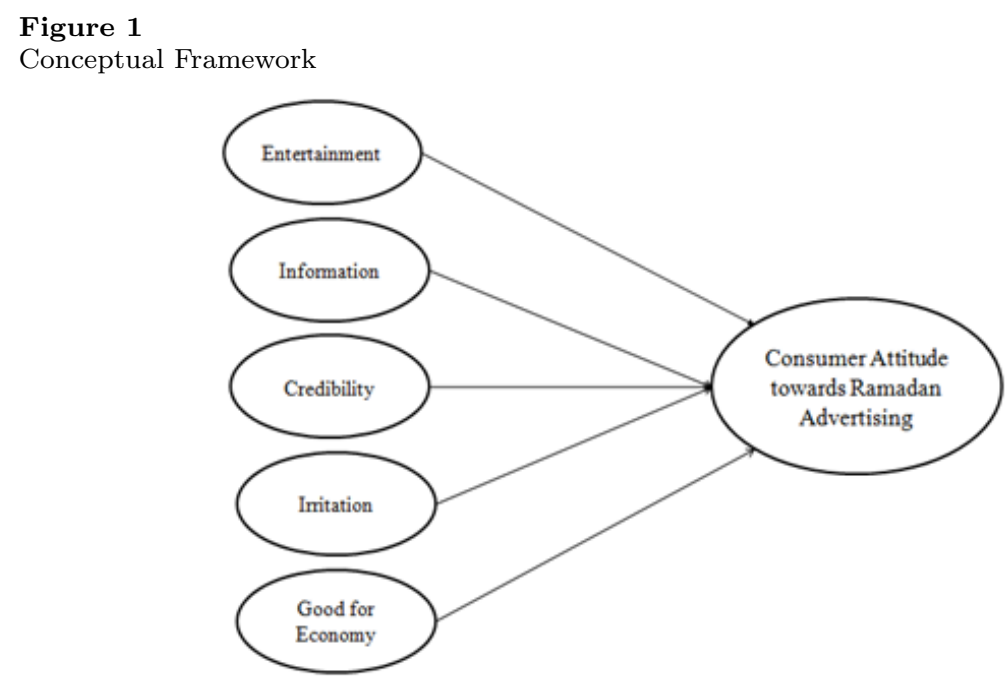

Consumer attitude towards an advertisement is important from marketing perspective as it reflects his feelings, thoughts and purchase intention (Mehta, 2000; Aleem, 2015). These findings are consistent to earlier studies in which audience behavior towards a particular advertisement was measured on a based on bi-polar scale (favorable/unfavorable) (MacKenzie \& Lutz, 1989; Spielmann \& Richard, 2013). Several studies found irritation, information, and credibility effect attitude towards festival advertising. Therefore, it is presumed that this relationship of attitude towards advertising will be true for Ramadan advertising (Spielmann \& Richard, 2013).

\section{Entertainment and Attitude}

Studies have found advertisements offering hedonic benefits are more successful as they encourage consumers to form positive attitude towards these types of advertisements (Li, Ngai, \& Xu, 2015). Advertisements with entertainment appeal have a higher attraction, which again leads to positive attitude towards advertising (Jager \& Eisend, 2013). Others while validating the relationship of entertainment and attitude towards advertising also suggested that some of the factors associated with entertainment advertising appeal are humorous and musical (Hegner, Kusse, \& Pruyn, 2016; Jager \& Eisend, 2013). Thus, it has been hypothesized that:

$H_{1}$ : Consumer attitude towards Ramadan Advertising will increase positively if it contains entertainment aspects. 


\section{Information and Attitude}

Advertising plays a significant role in communicating information about the products and/or brands to consumers. Information thus, is an important factor of advertising.Studies in the domain of online advertising also found a strong relationship between information seeking and attitude towards advertising. Consumers' attitudes are positive towards those advertisement that have information appeal. These types of advertisements induce trial, which is an important aspect of marketing. Advertising becomes more effective if it provides information related to consumers' needs and in accordance to their language and culture (Gillespie \& Joireman, 2016; Lambrecht \& Tucker, 2013). Advertisements that are easy to understand will have a higher level of consumers' goodwill about the products or brands (Feng, Fu, \& Qin, 2016). Others also support that there is strong relationship between information and attitude towards advertising (Dewan \& Ramaprasad, 2014). Thus it has been hypothesized that:

$\mathrm{H}_{2}$ : Consumer attitude towards Ramadan Advertising will increase positively if it is informative in nature.

\section{Credibility and Attitude}

Credibility refers to consumer's perception towards an advertisement in the context of its reliability and trustworthiness (Wu et al., 2016). Consumers play an active role in print ads and passive role in TV ads. Studies found that the former is more credible than the later (Ji, Michaels, \& Waterman, 2014). Besides the factors discussed above, the credibility of the person appearing in the advertisement is a significant factor in advertising (Zha, Li, \& Yan, 2015). Others while substantiating the relationship between credibility and attitude towards advertising observed that credibility of the endorser positively influences attitude towards advertising (Wu et al., 2016; Yang, Kim, \& Yoo, 2013). Thus it has been hypothesized that:

$H_{3}$ : Consumer attitude towards Ramadan Advertising will increase positively if it is credible.

\section{Irritation and Attitude}

Consumers are irritated with the advertisements that contain offending or insulting messages (Dahlen et al., 2014). Consequently, they form negative attitude towards such advertisements (Klimin \& Tikhonov, 2016). For example, in case of mobile advertising consumers get irritated due to the continuous inflow of unsolicited advertising, consequently they get confused and react negatively towards such messages (Yang et al., 2013). Thus it has been hypothesized that:

$H_{4}$ : Consumer attitude towards Ramadan Advertising will increase negatively with irritable content. 


\section{Good for Economy and Attitude}

Consumers reaction towards an advertisement depend on how they have comprehended the messages (Lorek \& Spangenberg, 2014). Good for economy advertisement are those that motivate and influence consumers to new technology (Jung et al., 2016). Other positive effects of such advertisements are that they help in generating employment, reducing production cost and promoting healthy competition (De Clercq, Lim, \& Oh, 2013). Additionally, it provides product's information to consumers, and increases people's living standards. Thus all the business activity are significantly dependent on advertising communication. In this context, studies have validated that good for economy advertisements helps in enhancing consumer's standard of living and provides updated and reliable information to consumers (Jiang \& Srinivasan, 2016; Lorek \& Spangenberg, 2014). Studies found that some of the major advantages of advertising are that it increases standard of living, it provides accurate and reliable information that decreases searching cost (De Clercq et al., 2013; Saadeghvaziri, Dehdashti, \& Reza Kheyrkhah Askarabad, 2013). Thus, it has been hypothesized that:

$H_{5}$ : Consumer attitude towards Ramadan Advertising will increase positively that contains content that are good for the economy.

\section{Methodology}

\section{Procedure}

The used approach in this paper is deductive in nature. The population for this research is about 2.7 million households in Pakistan (Mughal, 2014) and sample size is 303. Households are selected as population because they are more exposed to advertisements especially during the month of Ramadan due to gatherings at sehry \& Iftar (El-Bakry, 2001). Thus, the used sampling technique for this paper is convenience sampling as sample-frame for this research is not available (Bryman, 2015).

\section{Scale and Measure}

All the adopted constructs used in the study are from the earlier developed constructs, which were converted to seven point Likert Scale. Scholars suggest that the results of 7point Likert Scale produce stronger correlations with t-test results (Lewis, 2007). Studies found that respondents feel comfortable while filling out such questionnaire (Refer to Table 1 for the details). 


\section{Results}

\section{Profile of the Respondents}

Of the total respondents of 303 respondents, 206 (68\%) were males and the rest $87(32 \%)$ were females. Bulk of the respondents belonged to the age group of 18 to $30(70 \%)$ and the rest of them were of higher age groups. Single respondents were $230(76 \%)$ and the rest $73(24 \%)$ were married.

Table 1

Measures of Entertainment, Information, Credibility, Irritation and Attitude

\begin{tabular}{lccc}
\hline Construct & Author & Items & Reliability in Earlier Studies \\
\hline Entertainment (EN) & Jung (2009) & 5 & $\mathbf{0 . 9 8}$ \\
Information(IN) & Jung (2009) & 6 & 0.95 \\
Credibility(CR) & Jung (2009) & 4 & 0.94 \\
Irritation(IR) & Jung (2009) & 4 & 0.83 \\
Good for Economy(GFE) & Chai, Hoi \& Choon (2010) & 3 & 0.8 \\
Attitude towards Ramadan Advertising (AT) & Jun and Lee's (2007) & 4 & 0.84 \\
\hline
\end{tabular}

\section{Descriptive Statistics}

Skewness and Kurtosis analyses are used for ascertaining the uni-variate normality of the adopted constructs. The results are summarized in Table 2, below:

Table 2

Descriptive Analysis

\begin{tabular}{lcccc}
\hline Construct & Mean & Std. Dev. & Skewness & Kurtosis \\
\hline Attitude(AT) & 3.81 & 1.38 & 0.14 & -0.89 \\
Entertainment(EN) & 2.93 & 0.74 & -0.04 & -0.61 \\
Information(IN) & 3.72 & 1.55 & 0.16 & -0.97 \\
Credibility(CR) & 4.3 & 1.43 & -0.17 & -0.96 \\
Irritation(IR) & 4.31 & 1.53 & -0.06 & -0.96 \\
Good for Economy(GFE) & 4.07 & 1.43 & -0.03 & -0.62 \\
\hline
\end{tabular}

Table 2 above shows that the highest Skewness level (SK=-.17) is for the construct credibility $(\mathrm{CR})($ Mean=4.30, $\mathrm{SD}=1.43)$, and the lowest $(\mathrm{SK}=.03)$ is for the construct good for economy $(\mathrm{GFE})($ Mean $=4.07 \mathrm{SD}=1.43)$. Conversely the highest Kurtosis level $(\mathrm{KR}=-.97)$ is for the construct.

Entertainment $(\mathrm{EN})(\mathrm{Mean}=2.93, \mathrm{SD}=1.33)$. Thus all the adopted constructs fulfill uni-variate normality requirements as they ranged between \pm 2.5 (Park, 2015).

\section{Reliability Analysis}

Internal consistency of the adopted constructs has been measured through Cronbach's Alpha. Summarized results are depicted in Table 3, below. 
Table 3

\begin{tabular}{lcccc} 
Reliability Analysis & & & & \\
\hline Constructs & $\begin{array}{c}\text { Cronbach's Alpha } \\
\text { (Standardized) }\end{array}$ & $\begin{array}{c}\text { No } \\
\text { of items }\end{array}$ & Mean & SD \\
\hline Entertainment (EN) & 0.8 & 3 & 2.93 & 0.74 \\
Information(IN) & 0.91 & 3 & 3.72 & 1.55 \\
Credibility(CR) & 0.86 & 4 & 4.3 & 1.43 \\
Irritation(IR) & 0.87 & 3 & 4.31 & 1.53 \\
Good for Econ, (GFC) & 0.82 & 2 & 4.07 & 1.43 \\
Attitude (AT) & 0.87 & 4 & 3.81 & 1.38 \\
Overall(OV) & 0.95 & 19 & 3.85 & 1.79 \\
\hline
\end{tabular}

Table 3 shows that the highest reliability $(\alpha=.91)$ is for the construct information $(\mathrm{M}=3.72, \mathrm{SD}=1.55)$, while the reliability for good for economy ( $\mathrm{GFE})(\mathrm{M}=4.07, \mathrm{SD}=1.4)$ is the lowest $(\alpha=.42)$. The overall Cronbach's alpha for all the constructs is $(\alpha=.95$, Mean=3.85, $\mathrm{SD}=1.79)$. All the Cronbach's Alpha values are greater than .80 indicating good internal consistency (Hair, 2015; Iqbal \& Usmani, 2009).

\section{Exploratory Factor Analysis (EFA)}

EFA being explorative in nature was used for understanding relationships between the constructs and indicator variables. Table 4 shows the results.

Table 4

Exploratory Factor Analysis (EFA)

\begin{tabular}{lcccc}
\hline Constructs & Items & KMO & BToS & CFL \\
\hline Attitude(AT) & 4 & 0.84 & 526.71 & $60.26 \%$ \\
Entertainment(EN) & 5 & 0.78 & 389.68 & $58.28 \%$ \\
Information(IN) & 6 & 0.89 & 1032.17 & $74.17 \%$ \\
Credibility(CR) & 4 & 0.86 & 632.84 & $64.18 \%$ \\
Irritation(IR) & 4 & 0.86 & 755.42 & $66.39 \%$ \\
Good For Econ.(GFE) & 3 & 0.81 & 503.65 & $58.26 . \%$ \\
\hline Note: Kaiser Meyer Olkin, Bartlett Test of Sphericity, \\
Cumulative Factor Loading
\end{tabular}

Kaiser-Meyer-Olkin (KMO) for all the constructs is at least .78, which is greater than minimum value of .60. Bartlett's Test of Sphericity for all the constructs was significant at $95 \%$ confidence level. In addition, the cumulative factor loading for all the constructs are at least .50. Thus confirming the theoretical aspect of latent variables (Bryman, 2015).

\section{Correlation Analysis}

Correlation analysis was carried out ascertain the multi-co linearity issue and for ascertaining whether variables used are unique and distinct (Bryman, 2015).The results are summarized in Table 5 . 
Table 5

Bivariate Correlation

\begin{tabular}{lcccccc}
\hline Constructs & AT & EN & IN & CR & IR & GFE \\
\hline Attitude(AT) & 1 & & & & & \\
Information(IN) & 0.7 & 0.82 & 1 & & & \\
Credibility(CR) & 0.73 & 0.57 & 0.56 & 1 & & \\
Irritation(IR) & 0.71 & 0.53 & 0.57 & 0.6 & 1 & \\
Good for Economy(GFE) & 0.7 & 0.54 & 0.56 & 0.62 & 0.55 & 1 \\
\hline
\end{tabular}

Table 5 shows each relationship was significant at a $95 \%$ confidence level. The strongest relationship $(\mathrm{r}=.82)$ was for the pair information (IN) (Mean=3.72, SD =1.55) and entertainment $(\mathrm{EN})(\mathrm{Mean}=2.93, \mathrm{SD}=.74)$. On the other hand the weakest relation$\operatorname{ship}(\mathrm{r}=.53)$ was between the pair entertainment $(\mathrm{EN})($ Mean $=2.93, \mathrm{SD}=.74)$ and irritation $(\mathrm{IR})(\mathrm{Mean}=4.31, \mathrm{SD}=1.53)$. Since all the bi-variate relationships ranged between .30 to .90 , therefore it confirms that all the constructs are unique and distinct and there is no issue of multi-co-linearity (Zikmund, Babin, Carr, \& Griffin, 2013).

\section{Construct Validity}

Since all the constructs used in this research adopted from the West, therefore construct validity have also been ascertained through convergent and discriminant validity (Bryman, 2015).

\section{Convergent Validity}

The variance explained for each construct was greater than or approximately equal to .60 in addition, internal consistency were higher than 0.70 therefore the data fulfills the requirement of convergent validity (Hair, 2015). Table 6 shows the summarized results.

Table 6

Reliability of the constructs and Variance Explained

\begin{tabular}{lcccc}
\hline Constructs & $\begin{array}{c}\text { Cronbach's Alpha on } \\
\text { standardized item }\end{array}$ & $\begin{array}{c}\text { Variance } \\
\text { Explained }\end{array}$ & Mean & S.D \\
\hline Entertainment (EN) & 0.8 & 0.59 & 4.79 & 1.31 \\
Information(IN) & 0.91 & 0.74 & 3.97 & 1.45 \\
Credibility(CR) & 0.86 & 0.64 & 4.59 & 1.25 \\
Irritation(IR) & 0.87 & 0.66 & 4.36 & 1.27 \\
Good for Econ, (GFC) & 0.82 & 0.58 & 3.86 & 1.8 \\
Attitude (AT) & 0.87 & 0.6 & 5 & 1.33 \\
\hline
\end{tabular}

\section{Discriminant Validity}

Whether the constructs are unique and distinct or not was measured by discriminant analysis. Since the square root (sqrt) of variance are greater than the square of each pairs of correlation therefore is safely assumed that the constructs used in the study are unique and distinct. Table 7 shows the summarized results. 
Table 7

Discriminant Validity

\begin{tabular}{lcccccc}
\hline Constructs & AT & EN & IN & CR & IR & GFE \\
\hline Attitude(AT) & 0.79 & & & & & \\
Entertainment(EN) & 0.59 & 0.76 & & & & \\
Information(IN) & 0.49 & 0.67 & 0.86 & & & \\
Credibility(CR) & 0.53 & 0.32 & 0.31 & 0.8 & & \\
Irritation(IR) & 0.5 & 0.29 & 0.57 & 0.36 & 0.81 & \\
Good for Econ.(GFE) & 0.49 & 0.29 & 0.57 & 0.38 & 0.55 & 0.76 \\
\hline
\end{tabular}

\section{Overall Model Regression Test}

Multiple regression analysis is used to test the overall model that states "entertainment, information, credibility, irritation, and good for economy influence consumer's attitude towards advertising". Table 8 shows summarized results

Table 8

Overall model (Regression Results)

\begin{tabular}{lccccc}
\hline \multirow{2}{*}{ Variables } & Un stand. Coefficient & \multicolumn{2}{c}{ Std. Coefficient } & T & Sig \\
\cline { 2 - 4 } & $\mathrm{B}^{*}$ & Std. Error & Beta & & \\
\hline (Constant) & -0.26 & 0.13 & - & -2.01 & 0.05 \\
Information (IN) & -0.01 & 0.04 & -0.01 & -0.19 & 0.85 \\
Credibility (CR) & 0.21 & 0.03 & 0.23 & 5.99 & 0.00 \\
Irrational(IR) & 0.21 & 0.03 & 0.24 & 6.4 & 0.00 \\
Good For Econ(GFE) & 0.21 & 0.04 & 0.22 & 5.96 & 0.00 \\
Entertainment(EN) & 0.73 & 0.09 & 0.39 & 7.88 & 0.00 \\
\hline Dependent Variable: Consumer Attitude towards Ramadan & Advertising (AT), \\
R2 $=.78$ Adjusted R2 $=.74, \mathrm{P}<.05, \mathrm{~F}(5,298)=220.56$ & \multicolumn{4}{l}{}
\end{tabular}

Table: 8 shows that the combined effects of predictors information(IN), credibility(CR), irritation(IR), entertainment(EN) and good for economy (GOE) on attitude towards Ramadan advertising (AT) is $74 \%(\mathrm{R} 2=0.74, \mathrm{P}<.05, \mathrm{~F}(5,298)=220.56, \mathrm{p}<.05)$, which is considered as a large effect (Bryman, 2015). Since the hypothesized model fitted significantly, therefore the effects of each predictor has been calculated separately in the following sections.

\section{Entertainment and Attitude:}

Simple regression was used to test the hypothesis "Consumer attitude towards Ramadan Advertising will increase positively if it contains entertainment aspects" Regression output is presented in Table 9 .

Table 9

Regression Results

\begin{tabular}{|c|c|c|c|c|c|}
\hline \multirow{2}{*}{ Variables } & \multicolumn{2}{|c|}{ Unstandardized Coefficient } & \multirow{2}{*}{$\begin{array}{c}\text { Standard Coefficient } \\
\text { Beta }\end{array}$} & \multirow{2}{*}{$\mathrm{T}$} & \multirow{2}{*}{ Sig } \\
\hline & B & Std Error & & & \\
\hline Constant & 1.01 & 0.14 & - & 7.09 & - \\
\hline Entertainment & 1.5 & 0.07 & 0.77 & 21.11 & 0.00 \\
\hline
\end{tabular}


Table 9 above shows that entertainment (EN) causes a variance $59 \%$ to attitude towards advertising (AT), Adjusted $\mathrm{R} 2=.59, \mathrm{~F}(1,302)=445.54, \mathrm{P}<.05$. Additionally, the effect of entertainment on attitude $(\beta=.77)$, which is a large effect (J. Cohen, 1988).

\section{Information and Attitude}

The hypothesis: "Consumer attitude towards Ramadan Advertising will increase positively if it is informative in nature" tested through simple regression (see Table 10 below).

Table 10

Regression Output

\begin{tabular}{cccccc}
\hline \multirow{2}{*}{ Variables } & \multicolumn{2}{c}{ Unstandardized Coefficient } & Standard Coefficient & \multirow{2}{*}{$\mathrm{T}$} & Sig \\
\cline { 2 - 3 } & $\mathrm{B}$ & Std Error & Beta & & \\
\hline Constant & 1.48 & 0.15 & - & 9.94 & 0.00 \\
Information & 0.63 & 0.04 & 0.7 & 16.99 & 0.00 \\
\hline Dependent Variable: Attitude towards Ramadan Advertising (AT) & & \\
$\mathrm{R} 2=.49 ;$ Adjusted R2 $=.49, \mathrm{~F}(1,302)=288.69, \mathrm{P}<.05$. & &
\end{tabular}

Table 10 above shows that information (IF) causes a variance of $49 \%$ to attitude towards advertising $(\mathrm{AT}), \mathrm{R} 2=.49 ;$ Adjusted $\mathrm{R} 2=.49, \mathrm{~F}(1,302)=288.69, \mathrm{P}<.05$. Additionally, the effect of information on attitude $(\beta$.70) which is a large effect (J. Cohen, 1988).

\section{Credibility and Attitude}

The hypothesis that "Consumer attitude towards Ramadan Advertising will increase positively if it is credible" was tested through simple regression, which is summarized in Table 11.

Table 11

Regression Output

\begin{tabular}{cccccc}
\hline \multirow{2}{*}{ Variables } & \multicolumn{2}{c}{ Unstandardized Coefficient } & Standard Coefficient & \multirow{2}{*}{ T } & Sig \\
\cline { 2 - 4 } & $\mathrm{B}$ & Std Error & \multicolumn{2}{c}{ Beta } & \\
\hline Constant & 1.48 & 0.15 & 0.7 & 0.00 \\
Credibility & 0.63 & 0.04 & 16.99 & 0.00 \\
\hline Dependent Variable: Attitude towards Ramadan Advertising $(\mathrm{AT})$, & \\
R2 $=.66 ;$ Adjusted R2 $=.65, \mathrm{~F}(1,302)=291.99, \mathrm{P}<.05$.
\end{tabular}

Table 11 shows that credibility (CR) causes a variance of $66 \%$ to attitude towards advertising $(\mathrm{AT}), \mathrm{R} 2=.66$; Adjusted $\mathrm{R} 2=.65, \mathrm{~F}(1,302)=291.99, \mathrm{P}<.05$. Additionally, the effect of credibility on attitude $(\beta$.70) which is a large effect (J. Cohen, 1988).

\section{Irritation and Attitude}

The hypothesis that "Consumer attitude towards Ramadan Advertising will increase negatively with irritable content", was tested through simple regression and the summarized results are presented in Table 12 below 
Table 12

Summarized Regression Results

\begin{tabular}{lccccc}
\hline \multirow{2}{*}{ Variables } & \multicolumn{2}{l}{ Unstandardized Coefficient } & Standard Coefficient & \multirow{2}{*}{$\mathrm{T}$} & Sig \\
\cline { 2 - 3 } & $\mathrm{B}$ & Std Error & Beta & & \\
\hline Constant & 1.01 & 0.17 & - & 6.08 & 0.00 \\
Irritation & 0.65 & 0.04 & 0.72 & 17.94 & 0.00 \\
\hline Dependent Variable: Attitude towards Ramadan Advertising (AT) & \\
$\mathrm{R} 2=.52 ;$ Adjusted $\mathrm{R} 2=.51, \mathrm{~F}(1,302)=321.76, \mathrm{P}<.05$. & &
\end{tabular}

Table 12, above shows that irritation (IR) causes a variance of $52 \%$ to attitude towards advertising $(\mathrm{AT}), \mathrm{R} 2=.52$; Adjusted $\mathrm{R} 2=.52, \mathrm{~F}(1,302)=321.76, \mathrm{P}<.05$. Additionally, the effect of irritation on attitude $(\beta=.72)$ which is a large effect (J. Cohen, 1988).

\section{Good for Economy and Attitude}

The hypothesis "Consumer attitude towards Ramadan Advertising will increase positively that contains content that are good for the economy" was tested through regression analysis. The summarized results are presented in Table 13 below:

Table 13

Summarized Regression Results

\begin{tabular}{llcccc}
\hline \multirow{2}{*}{ Variables } & \multicolumn{2}{c}{ Unstandardized Coefficient } & Standard Coefficient & \multirow{2}{*}{ T } & Sig \\
\cline { 2 - 3 } & $\mathrm{B}$ & Std Error & Beta & & \\
\hline Constant & 1.06 & 0.17 & - & 6.15 & 0.00 \\
Good for Econ & 0.68 & 0.04 & 0.69 & 16.93 & 0.00 \\
\hline Dependent Variable: Attitude towards Ramadan Advertising (AT), & & \\
R2 = .49; Adjusted R2 $=.48, \mathrm{~F}(1,302)=286.76, \mathrm{P}<.05$. & &
\end{tabular}

Table 13 above shows that Good for economy (GFE) causes a variance of $59 \%$ to attitude towards advertising $(\mathrm{AT}), \mathrm{R} 2=.59$; Adjusted $\mathrm{R} 2=.58, \mathrm{~F}(1,302)=286.76$, $\mathrm{P}<.05$. Additionally, the effect of good for economy on attitude $(\beta=.69)$ which is a large effect (J. Cohen, 1988).

\section{Discussion and Conclusion}

\section{Discussion}

Today's consumers have more empowerment, products, and services at their disposal. This has increased the competition intensively and firms are relying significantly on advertisements for communicating their value proposition (Camacho, De Jong, \& Stremersch, 2014).

The hypothesis on the effect of "perceived entertainment on consumer attitude towards Ramadan advertising" failed to be rejected (Refer to Table 9). Advertisements with entertainment appeal have a higher attraction appeal, which again leads to positive attitude towards advertising (Jager \& Eisend, 2013). Others while validating the relationship of entertainment and attitude towards advertising also suggested that some of the factors 
associated with entertainment advertising appeal are humorous, musical (Hegner et al., 2016; Jager \& Eisend, 2013).

The hypothesis on the effect of "information on the attitude towards advertisements failed to be rejected (Refer to Table 10). Studies in the domains of online advertising also found a strong relationship between information seeking and attitude towards advertising (Lambrecht \& Tucker, 2013). Advertising effectives increases if it communicates provides information related to consumers' needs and in accordance to their language and culture. Others also support that there is strong relationship between information and attitude towards advertising (Dewan \& Ramaprasad, 2014; Gillespie \& Joireman, 2016; Lambrecht \& Tucker, 2013).

The hypothesis that "credibility has positive effect on the consumer attitude towards Ramadan advertising" failed to be rejected (Refer to Table 11). The credibility of the person appearing in the advertisement is a significant factor (Zha et al., 2015). Others while substantiating the relationship between credibility and attitude towards adverting observed that credibility of the endorser positively influences attitude towards advertising (Wu et al., 2016; Yang et al., 2013).

The hypothesis "irritation has negative effect on the consumer attitude towards Ramadan advertising" was rejected (Refer to Table 12). This finding is contrary to earlier studies. Consumers are generally irritated with the advertisements that contain offending or insulting messages. Consequently, they form negative attitude towards such advertisements. For example, in case of mobile advertising consumers get irritated due to the continuous inflow of unsolicited advertising consequently they get confused and react negatively towards such messages (Dahlen et al., 2014; Klimin \& Tikhonov, 2016; Yang et al., 2013).

The hypothesis that "advertisements that are good for economy will positively affect consumer attitude towards Ramadan advertising" was substantiated (Refer to Table 13). Good for economy advertisement are those that motivate and influence consumers to new technology. Other positive effects of such advertisements are that they help in generating employment, reducing production cost and promoting healthy competition. Additionally, it provides product's information to consumers, and increases people's living standards. Thus all the business activity are significantly dependent on advertising communication (De Clercq et al., 2013).

\section{Implication for Managers and Policy Makers}

In view of the positive effects predictors "entertainment, information, credibility and good for economy on attitude towards Ramadan advertising (AT)" could be incorporated in the communication strategies. Irritations aspects could only be incorporated if the desired objective is breaking the clutter and getting consumers attention. While developing the communication strategy, marketers must identify which of the factors is their strength, and communicate only those. Focusing on too many factors might confuse the consumers. 


\section{Limitation and Future Research}

The scope of this study was towards households in Karachi. Future studies could further enhance their scope by extending to the households across the country. Demographic factors could also be incorporated in future studies, which was beyond the scope of this study. The constructs used in this paper were adopted from the studies that were mainly used for measuring attitude towards advertising. The findings of this study suggest for the development of constructs related to the theme of advertising will bring further insight on the issue. 


\section{References}

Aleem, M. S. (2015). The right marketing tactics to target restaurants. South Asian Journal of Management Sciences (SAJMS), Iqra University, 9(2), 49-62.

Bauer, H. H., Reichardt, T., Barnes, S. J., \& Neumann, M. M. (2005). Driving consumer acceptance of mobile marketing: A theoretical framework and empirical study. Journal of Electronic Commerce Research, 6(3), 181-192.

Bhave, K., Jain, V., \& Roy, S. (2013). Understanding the orientation of gen Y toward mobile applications and in-app advertising in India. International Journal of Mobile Marketing, 8(1), 62-74.

Bryman, A. (2015). Social research methods. Oxford University Press.

Camacho, N., De Jong, M., \& Stremersch, S. (2014). The effect of customer empowerment on adherence to expert advice. International Journal of Research in Marketing, $31(3), 293-308$.

Cohen, J. (1988). Statistical power analysis for the behavioral sciences. NJ: Lawrence Earlbaum Associates.

Cohen, J. (2014). Promoting pleasure as political economy: The transformation of American advertising, 1800 to 1850. Winterthur Portfolio, 48(2/3), 163-190.

Cohen, L., Manion, L., \& Morrison, K. (2013). Research methods in education. Routledge.

Dahlen, M., Rosengren, S., \& Smit, E. (2014). Why the marketer's view matters as much as the message. Journal of Advertising Research, 54(3), 304-312.

Daniel, A., \& Raman, A. (2014). Revisiting the issue of marketing education and professional practice in Nigeria. Global Journal of Management And Business Research, 13(10). Retrieved from https://www. journalofbusiness .org/index.php/GJMBR/ article/view/1171

De Clercq, D., Lim, D. S., \& Oh, C. H. (2013). Individual-level resources and new business activity: The contingent role of institutional context. Entrepreneurship Theory and Practice, 37(2), 303-330.

Dewan, S., \& Ramaprasad, J. (2014). Social media, traditional media, and music sales. Mis Quarterly, 38(1), 101-121.

Ducoffe, R. H. (1996). Advertising value and advertising on the web. Journal of Advertising Research, 36(5), 21-21.

El-Bakry, R. (2001). Ramadan karim- That's L. E. 20, please. Business Today Egypt, p. 14 .

Evans, N. J., \& Hoy, M. G. (2016). Parents' presumed persuasion knowledge of children's advergames: The influence of advertising disclosure modality and cognitive load. Journal of Current Issues \& Research in Advertising, 37(2), 146-164.

Fattah, M. H. (2005). The new ramadan: It's beginning to look a lot like. The New York Times.

Feng, X., Fu, S., \& Qin, J. (2016). Determinants of consumers' attitudes toward mobile advertising: The mediating roles of intrinsic and extrinsic motivations. Computers in Human Behavior, 63(5), 334-341.

Fishbein, M., \& Ajzen, I. (1975). Belief. attitude, intention and behavior: An introduction to theory and research reading. MA: Addison-Wesley. 
Gatehouse, J. (2001). The holiest month. Maclean's, 114(51), 18-22.

Gharib, S. (1992). Egypt: A national obsession. UNESCO Courier, 45(10), 33-36.

Gillespie, B., \& Joireman, J. (2016). The role of consumer narrative enjoyment and persuasion awareness in product placement advertising. American Behavioral Scientist, $60(12), 1510-1528$.

Hair, J. F. (2015). Essentials of business research methods. London: ME Sharpe.

Hegner, S. M., Kusse, M. D. C., \& Pruyn, A. T. (2016). Watch it the influence of forced pre-roll video ads on consumer perceptions. In Advances in advertising research. Springer.

Helm, A. E., Moulard, J. G., \& Richins, M. (2015). Consumer cynicism: Developing a scale to measure underlying attitudes influencing marketplace shaping and withdrawal behaviours. International Journal of Consumer Studies, 39(5), 515-524.

Iqbal, A., \& Usmani, S. (2009). Factors influencing individual investor behavior (The Case of the Karachi Stock Exchange). South Asian Journal of Management Sciences, 3(1), $15-26$.

Jager, T., \& Eisend, M. (2013). Effects of fear-arousing and humorous appeals in social marketing advertising: The moderating role of prior attitude toward the advertised behavior. Journal of Current Issues 8 Research in Advertising, 34(1), 125-134.

Ji, S. W., Michaels, S., \& Waterman, D. (2014). Print vs. electronic readings in college courses: cost-efficiency and perceived learning. The Internet and Higher Education, 21(1), 17-24.

Jiang, B., \& Srinivasan, K. (2016). Pricing and persuasive advertising in a differentiated market. Marketing Letters, 27(3), 579-588.

Jung, J., Shim, S. W., Jin, H. S., \& Khang, H. (2016). Factors affecting attitudes and behavioural intention towards social networking advertising: A case of Facebook users in South Korea. International Journal of Advertising, 35(2), 248-265.

Kim, Y. J., \& Han, J. (2014). Why smartphone advertising attracts customers: A model of web advertising, flow, and personalization. Computers in Human Behavior, 33(1), 256-269.

Klimin, A., \& Tikhonov, D. (2016). Perception of offensive advertising: Cross-cultural peculiarities. In Cross-Cultural Business Conference 2016.

Lambrecht, A., \& Tucker, C. (2013). When does retargeting work information specificity in online advertising. Journal of Marketing Research, 50(5), 561-576.

Lewis, V. J. (2007). Productivity and the Euro-Dollar real exchange rate. Review of World Economics, $143(2), 324-348$.

Li, J., Ngai, E., \& Xu, X. (2015). Is a positive review always effective? Advertising appeal effect in the persuasion of online customer reviews. In Paper presented at the The Pacific Asia Conference on Information Systems (PACIS), Singpore, 164.

Ling, K. C., Piew, T. H., \& Chai, L. T. (2010). The determinants of consumers' attitude towards advertising. Canadian Social Science, 6(4), 114-126.

Lorek, S., \& Spangenberg, J. H. (2014). Sustainable consumption within a sustainable economy-beyond green growth and green economies. Journal of Cleaner Production, $63(1), 33-44$. 
MacKenzie, S. B., \& Lutz, R. J. (1989). An empirical examination of the structural antecedents of attitude toward the ad in an advertising pretesting context. The Journal of Marketing, 53(2), 48-65.

Mazhar, Y. (1998). Advertising in Ramadan. Egyptian Gazette, p. 3.

Mehta, A. (2000). Advertising attitudes and advertising effectiveness. Journal of Advertising Research, 40(3), 67-72.

Mittal, B. (1994). Public assessment of tv advertising: Faint praise and harsh criticism. Journal of Advertising Research, 34(1), 35-54.

Mughal, F. U. D. (2014). To Facilitate Growth of Free and Fair Media. Islamabad: PEMRA.

Naseri, A., \& Tamam, E. (2012). Impact of islamic religious symbol in producing favorable attitude toward advertisement. Revista de Administratie Publica si Politici Sociale, $8(1), 61-78$.

Noor, M. N. M., Sreenivasan, J., \& Ismail, H. (2013). Malaysian consumers attitude towards mobile advertising, the role of permission and its impact on purchase intention: a structural equation modeling approach. Asian Social Science, 9(5), 135-148.

Odabasi, Y., \& Argan, M. (2009). Aspects of underlying Ramadan consumption patterns in Turkey. Journal of International Consumer Marketing, 21(3), 203-218.

Opree, S. J., Buijzen, M., van Reijmersdal, E. A., \& Valkenburg, P. M. (2014). Children's advertising exposure, advertised product desire, and materialism: A longitudinal study. Communication Research, 41(5), 717-735.

Osman, H. (1998). Advertisers see cash cow in Ramadan. Middle East Times, p. 4. Ramadan.

Park, H. M. (2015). Univariate analysis and normality test using SAS, Stata, and SPSS.

Rajabi, M., Dens, N., De Pelsmacker, P., \& Goos, P. (2017). Consumer responses to different degrees of advertising adaptation: The moderating role of national openness to foreign markets. International Journal of Advertising, 36(2), 293-313.

Rengarajan, P., \& Sathya, R. (2014). A study on impact of celebrity endorsement on brand perception and buying behavior of consumer with reference to udumalpet taluk. EPRA International Journal of Economics and Business Review, 2(12), 3742.

Saadeghvaziri, F., Dehdashti, Z., \& Reza Kheyrkhah Askarabad, M. (2013). Web advertising: Assessing beliefs, attitudes, purchase intention and behavioral responses. Journal of Economic and Administrative Sciences, 29(2), 99-112.

Sandikci, O., \& Omeraki, S. (2007). Globalization and rituals: Does Ramadan turn into Christmas? ACR North American Advances, 34(1), 610-615.

Spielmann, N., \& Richard, M.-O. (2013). How captive is your audience? Defining overall advertising involvement. Journal of Business Research, 66 (4), 499-505.

Tina, W., \& Buckner, K. (2006). Receptiveness of gamers to embedded brand messages in advergames: Attitudes towards product placement. Journal of Interactive Advertising, 7(1), 3-32.

Tucciarone, K. (2015). Star power: Elevating prospective student interest through expert and celebrity endorsements-relevant message, relevant media. College and University, $91(1), 22-32$. 
Usmani, S., \& Dawani, K. (2013). Teaching methods and their impact on performance of university students. South Asian Journal of Management Sciences, 7(1), 19-30.

Wu, M., Huang, Y., Li, R., Bortree, D. S., Yang, F., Xiao, A., \& Wang, R. (2016). A tale of two sources in native advertising: Examining the effects of source credibility and priming on content, organizations, and media evaluations. American Behavioral Scientist, $60(12), 1492-1509$.

Yang, B., Kim, Y., \& Yoo, C. (2013). The integrated mobile advertising model: The effects of technology-and emotion-based evaluations. Journal of Business Research, 66 (9), 1345-1352.

Zha, X., Li, J., \& Yan, Y. (2015). Advertising value and credibility transfer: attitude towards web advertising and online information acquisition. Behaviour $\mathscr{E}$ Information Technology, 34(5), 520-532.

Zikmund, W. G., Babin, B. J., Carr, J. C., \& Griffin, M. (2013). Business research methods, (9-e). United States: Cengage Learning. Retrieved from https://books .google. com. my/books? id=ydcKAAAAQBAJ 